\title{
HISTORIA Y CIENCIAS SOCIALES EN TIEMPOS DE CRISIS
}

\author{
HISTORY AND SOCIAL SCIENCES \\ IN TIMES OF CRISIS
}

\author{
Karelia Cerda Castro* \\ Alberto Díaz Araya**
}

El presente número de Diálogo Andino, Revista de Historia, Geografía y Cultura Andina, busca aportar miradas críticas a conflictos y resistencias que involucran a distintas poblaciones y territorios. Inmersos en un complejo panorama nacional, tras el denominado "Estallido Social" del pasado 18 de octubre de 2019, el análisis desde distintos ámbitos de la Historia y las Ciencias Sociales se torna más necesario que nunca, para posibilitar una comprensión integral de fenómenos pasados y presentes que se inscriben en las dinámicas relacionales entre el Estado y otros centros de poder con la sociedad civil.

En tiempos de convulsión y adversidades, la investigación científica puede aportar elementos claves para la reflexión en torno al desarrollo humano, hoy enfrentamos una crisis sanitaria global, producto de la pandemia del virus COVID19 , lo cual nos supone nuevos desafíos futuros en torno a la construcción de sociedad y ciudadanía en aspectos políticos, económicos, territoriales, culturales, etc. Por otra parte, este contexto de crisis nos abre interrogantes y posibilidades respecto del quehacer científico y, particularmente sobre la escritura de la Historia, pues desde el presente no solo elaboran cuestionamientos al pasado, sino que se manifiesta una emergencia por problematizar el propio presente, formulando desde la historiografía aproximaciones a lo contemporáneo, a esa historia que está pasando. Como señala Julio Aróstegui

"Tal Historia representaría la posibilidad y la necesidad de entender como históricos todos los instantes que se encadenan en nuestra conciencia de lo cotidiano. De esta forma, volvemos a encontrarnos otra vez con una ya antigua convicción: la de que las épocas de crisis profunda vuelven su mirada de forma acuciante para encontrar nuevas respuestas en la Historia. Y de esas preguntas nacen, entre otras cosas no menos importantes, nuevas concepciones y nuevas maneras de escribir la Historia" (Aróstegui:1996:18).

Este número presenta once artículos en los que se abordan temáticas relacionadas con violencias hacia poblaciones indígenas, resistencias culturales, problemáticas demográficas y conflictos medioambientales, desde diversas disciplinas.

En primer lugar, Carlos Contreras en su artículo titulado "La crisis demográfica del siglo XVI en Los Andes: una discusión acerca de sus dimensiones, cronología y consecuencias" analiza el impacto de la temprana presencia hispana en la zona de Perú, la cual se tradujo en una drástica reducción de la cantidad de población aborigen, a la vez que incidió en una transformación de la estructura económica de la zona; el autor problematiza las cifras de la población local previa a la llegada de los españoles entregadas por diversos autores, con la finalidad de generar una aproximación más certera y, desde ahí, analizar su disminución en las primeras etapas de asentamiento hispano y sus posteriores consecuencias para el sur Andino. Por su parte, los investigadores José Zavala, Tom Dillehay y Francisco Medianero en "Economía aurífera, caminos y fuertes en La Araucanía del siglo XVI: en torno

\footnotetext{
* Universidad de Tarapacá. Departamento de Ciencias Históricas y Geográficas. Correo electrónico: kcerdac@uta.cl

** Universidad de Tarapacá. Departamento de Ciencias Históricas y Geográficas. Correo electrónico: albertodiaz@uta.cl
} 
a la información de Martín Ruíz de Gamboa de 1579 " presentan un interesante trabajo documental y multidisciplinar, respecto de las dinámicas de la economía basada en la extracción de oro en la Araucanía, en las reducciones indígenas, y su importancia para el asentamiento hispano. El artículo de Paula Martínez Sagredo titulado "Sobre la castellanización de los indígenas en los andes coloniales: escuelas, materiales y maestros", aborda las características de la educación hispana aplicada sobre la población americana, especialmente en el contexto del sur de Los Andes coloniales, como mecanismo para la evangelización de la población nativa, proceso que no estuvo exento de dificultades y resistencias por parte de los indígenas.

En relación a conflictos territoriales y por recursos naturales, Karen Manzano y Diego Jiménez analizan el diálogo geopolítico entre Chile y Bolivia respecto de recursos hídricos -el cual a futuro se desarrollaría en términos de pugnas entre ambos Estados- involucrando tanto el uso de las aguas del Titicaca como la vía de acceso marítimo reclamada por el gobierno boliviano, en un contexto histórico marcado por el proyecto industrializador en los países latinoamericanos. Por su parte, Karenn Díaz analiza otro conflicto relacionado con el uso de aguas, desde una perspectiva jurídica, en este caso entre el Estado chileno y los pueblos originarios del Desierto de Atacama, en el cual se contraponen los derechos ancestrales y el uso comunitario del agua de los pueblos originarios con la mirada nacional y jurídica del Estado, cuya Constitución -centro del actual debate político y social- no otorga reconocimiento a la interculturalidad en esta materia. En una dirección similar, Daniela Escalona reflexiona sobre los conflictos medioambientales entre la comunidad indígena de Cancosa con la gran minería -HP Billiton- y la carencia de instancias de negociación que permitan un diálogo efectivo entre ambas partes, para satisfacer al reconocimiento de los derechos de los pueblos originarios vigentes en la legalidad chilena y la defensa de sus comunidades.

Pedro Canales, examina la transformación de la propiedad de tierras mapuche sobre la vida de quienes habitaban la reducción "Gallardo Tranamil", en la provincia de Cautín, sur de Chile; el manuscrito titulado "La división de las tierras mapuche en la reducción Gallardo Tranamil 1979-1985" analiza el contexto en que se implementó el Decreto-ley 2.568 -marcado por la Dictadura Cívico-Militar- como culminación de un proceso de liquidación de la propiedad comunitaria, para dar paso a la propiedad individual de la tierra, en ese sentido el Estado chileno tuvo como proyecto la asimilación de las y los mapuche en la sociedad chilena, impactando por tanto en sus formas de vida y relaciones sociales propias de sus comunidades. Si bien esta medida fue adoptada en un contexto de dictadura, en el cual la oposición al régimen tenía graves consecuencias represivas, el autor plantea que surgió resistencia mapuche organizada en rechazo de ésta por cuanto atentaba contra la ancestralidad y la vida del pueblo mapuche. Una similar aproximación al conflicto territorial mapuche en Arauco, es presentado por Alejandro Clavería, Jorge Iván Vergara y Hans Gundermann, quienes rescatan desde la oralidad las luchas colectivas mapuches por la restitución de sus tierras, en donde han mediado distintas formas y ejercicios de violencias, por otra parte reflexionan sobre la particularidad del contexto de Arauco por la vinculación de líderes sindicales y de partidos de izquierda en esta lucha.

Por su parte, "Resistencias locales frente a los diseños globales mediante las manifestaciones artísticas religiosas sincréticas. Caso: las negreras de Mosquey, Boconó-Trujillo, Venezuela", del investigador Felipe Bastidas, gira en torno a sincretismos culturales -específicamente en torno a la religiosidad-como mecanismos de resistencias de la identidad de la población andina de Mosquey en su tránsito de la vida rural al mundo urbano, proceso en el cual se presentan mecanismos que permiten, según el autor, evitar la desarticulación de su identidad local. Rossana Mendoza, Sara Alvarado y Adriana Aroyo, desarrollan "Jóvenes quechuas del sur andino del Perú desde una mirada decolonial", este escrito presenta un análisis decolonial respecto de la juventud quechua en el Perú actual, reflexionando sobre sus realidades -tanto en sus comunidades como en el contexto urbano- y las formas de mantener su identidad cultural bajo las concepciones propias del "Buen Vivir", en el marco del Neoliberalismo imperante, dicho análisis resulta sugerente al dar relevancia a 
sujetos eclipsados por el adultocentrismo que ha operado como lógica en las Ciencias Sociales, permitiendo entender a una subalteridad en el centro del análisis del presente peruano. Finalmente, Alfonso Díaz y Raúl Bustos proporcionan un análisis cuyas implicancias atraviesan el siglo $\mathrm{XX}$ en el extremo norte de Chile, en relación con la reconfiguración de las fronteras nacionales tras la firma del Tratado de Paz de 1929 entre Perú y Chile, en ese sentido reflexionan sobre su impacto económico y político en las ciudades de Tacna y Arica.
A partir de los artículos contenidos en esta edición de Diálogo Andino, se espera aportar al debate social, desde una lectura presente de las problemáticas abordadas. La actual coyuntura puede asumirse como un desafío y una oportunidad de revitalización para la Historia y las Ciencias Sociales, incorporar al análisis crítico el sentido mismo de crisis que se ha instalado en nuestras sociedades, como un lugar desde donde situarnos para generar conocimiento científico capaz de responder a las exigencias que se plantean en este contexto.

\section{Referencias Citadas}

Aróstegui, Julio

1996 El presente como historia (La idea de un análisis histórico de nuestro tiempo). Actas del Primer Simposio de Historia Actual de La Rioja. Logroño, España, 1996. 